\title{
32. GEOMAGNETIC INTENSITY AND FIELD DIRECTION CHANGES ASSOCIATED WITH THE MATUYAMA/BRUNHES POLARITY REVERSAL, AS RECORDED IN A SEDIMENT CORE FROM THE NORTH PACIFIC ${ }^{1}$
}

\author{
Stanley M. Cisowski ${ }^{2}$
}

\begin{abstract}
A highly detailed paleomagnetic record of the Matuyama/Brunhes polarity reversal is recorded in clay sediment samples taken from North Pacific Ocean Drilling Program (ODP) Hole 145-884C. In this study, I analyzed $811-\mathrm{cm}^{3}$ samples, taken over $\sim 75$ $\mathrm{cm}$ of core and representing about $16 \mathrm{k} . \mathrm{y}$. of deposition time. Normalized intensity vs. depth plots indicate that at least $7 \mathrm{cycles}$ of substantial intensity fluctuation describe the transition period, with the virtual geomagnetic pole (VGP) moving from high southern to high northern latitudes entirely within the fourth observed cycle. Transitional poles associated with earlier and later intensity lows, as well as the poles that describe the actual VGP reversal path, are distributed in close proximity to the $270^{\circ}$ longitudinal meridian. This preference for the longitudinal band, which includes North America, also extends to the higher latitude reversed poles that precede the polarity transition. Because the sampling site is $\sim 90^{\circ}$ from this preferred longitude, the significance of Hole $884 \mathrm{C}$ 's VGP confinement remains obscure. However, these results are in general agreement with the high sedimentation rate reversal record obtained earlier from Hole 792A (ODP Leg 126), drilled about $3500 \mathrm{~km}$ to the southwest. These conformable directional and intensity results suggest that the field maintained a dipole configuration, perhaps with the addition of a strong secondary equatorial dipole, throughout most of the transition period.
\end{abstract}

\section{INTRODUCTION}

Hole $884 \mathrm{C}$ was drilled through $854 \mathrm{~m}$ of Cenozoic sediment on the lower flank of the Detroit Seamount $\left(51.45^{\circ} \mathrm{N}, 168.34^{\circ} \mathrm{E}\right)$, about $1000 \mathrm{~km}$ east of the southern tip of Kamchatka Peninsula, during Ocean Drilling Program (ODP) Leg 145. Long core measurements made on board ship (Fig. 1) indicated that the first (Matuyama/ Brunhes) geomagnetic polarity reversal occurred in Section 145$884 \mathrm{C}-6 \mathrm{H}-1$, at approximately $41 \mathrm{~m}$ below seafloor (mbsf). The sediment in this interval consisted of diatom ooze with clay, with an average mass sedimentation rate of $46.9 \mathrm{~m} / \mathrm{m}$.y., based on eleven biostratigraphic and magnetostratigraphic markers in the top $120 \mathrm{~m}$ of core from this site (Shipboard Scientific Party, 1993). The linearity of these datums on the depth vs. age plot suggests a highly uniform sedimentation rate over the past 870 k.y.

The combination of high sedimentation rate, low disturbance and near complete recovery, and relatively high remanence intensity, as indicated by the archive-half core measurements (Fig. 1), suggested this hole in particular as a candidate for obtaining a high-resolution record of the Matuyama/Brunhes polarity transition. Hole $884 \mathrm{C}$ data is provided in the Appendix.

\section{SAMPLING AND MEASUREMENT PROCEDURE}

Orientation of Core $145-884 \mathrm{C}-6 \mathrm{H}$ with respect to geographic coordinates was obtained from the standard ODP multishot camera and compass tool mounted on the top of the core barrel. Oriented $1-\mathrm{cm}^{3}$ plastic sample cubes were taken at $0.4-$ to $1.3-\mathrm{cm}$ intervals beginning at $21.3 \mathrm{~cm}$ in Section $145-884 \mathrm{C}-6 \mathrm{H}-1$ (40.618 mbsf), and continuing to $40.0 \mathrm{~cm}$ in Section 145-884C-6H-2. Duplicate samples from the same horizons were taken side-by-side at $10-$ to $20-\mathrm{cm}$ intervals within this sampled region. For this study, samples extending down to $94.1 \mathrm{~cm}$ in Section 145-884C-6H-1 (41.346 mbsf) were measured, so as to yield fairly symmetrical coverage about the VGP reversal, which occurred at $\sim 55.6 \mathrm{~cm}$ within Section $145-884 \mathrm{C}-6 \mathrm{H}-1$

\footnotetext{
'Rea, D.K., Basov, I.A., Scholl, D.W., and Allan, J.F. (Eds.), 1995. Proc. ODP, Sci. Results, 145: College Station, TX (Ocean Drilling Program).

${ }^{2}$ Department of Geological Sciences and Institute of Crustal Studies, University of California, Santa Barbara, CA 93106, U.S.A.
}

( $40.96 \mathrm{mbsf}$ ). The time period encompassed by the measured samples, as computed from the average accumulation rate, is approximately 16 k.y. In a future study, I intend to measure the deeper samples, to describe the magnetic field behavior immediately preceding the polarity transition proper.

Samples were subjected to three stepwise alternating-field (AF) demagnetizations along orthogonal axes at intervals of 5, 10, 20, 30, 40 , and $50 \mathrm{mT}$, on a $2 \mathrm{G}$ Enterprises non-tumbling sample degausser. After each demagnetizing step, the samples were measured on a $2 \mathrm{G}$ Enterprises cryogenic magnetometer. Demagnetizations were terminated at $50 \mathrm{mT}$ for most samples as the higher demagnetizing fields generally produced a high degree of scatter in the directional results, apparently because of the acquisition of spurious remanence during the AF demagnetization process. The duplicate samples were subjected to continuous thermal demagnetization, with measurements made within the cryogenic magnetometer while the samples were still at high temperature. Standard line fitting (Kirschvinck, 1980) was done on the linear portions of the orthogonal component plots of AF demagnetization to determine the characteristic remanence direction of each sample. Because $25 \%-50 \%$ of the natural remanent magnetization (NRM) remained after demagnetization to $50 \mathrm{mT}$, all line fits were anchored to the origin to give a better estimate of the characteristic remanent magnetization (ChRM) direction.

Following the AF demagnetization of the samples' NRMs, each sample was given an anhysteretic remanent magnetism (ARM) for normalization purposes by exposing the sample to a slowly decaying $100-\mathrm{mT}$ alternating field in the presence of a $0.1-\mathrm{mT}$ constant ambient field. The resulting ARM was then subjected to AF demagnetization at $20 \mathrm{mT}$ along three orthogonal axes (for about every tenth sample, AF demagnetization of ARM was conducted at the same multiple demagnetization steps employed for NRM demagnetization). Finally, initial bulk susceptibility was measured for each sample on a Geofyzika Brno Kappabridge.

To contrast their coercivity spectra, two adjacent samples with differing NRM intensities and directions (145-884C-6H-1, 48.4-49.4 and $49.6-50.6 \mathrm{~cm}$ ) were subjected to high field isothermal remanent magnetization (IRM) acquisition, by means of exposure to progressively higher fields from an electromagnet. Following exposure to a peak field of $600 \mathrm{mT}$, the samples were stepwise demagnetized along the same axis used in the IRM acquisition, up to an AF field of 150 

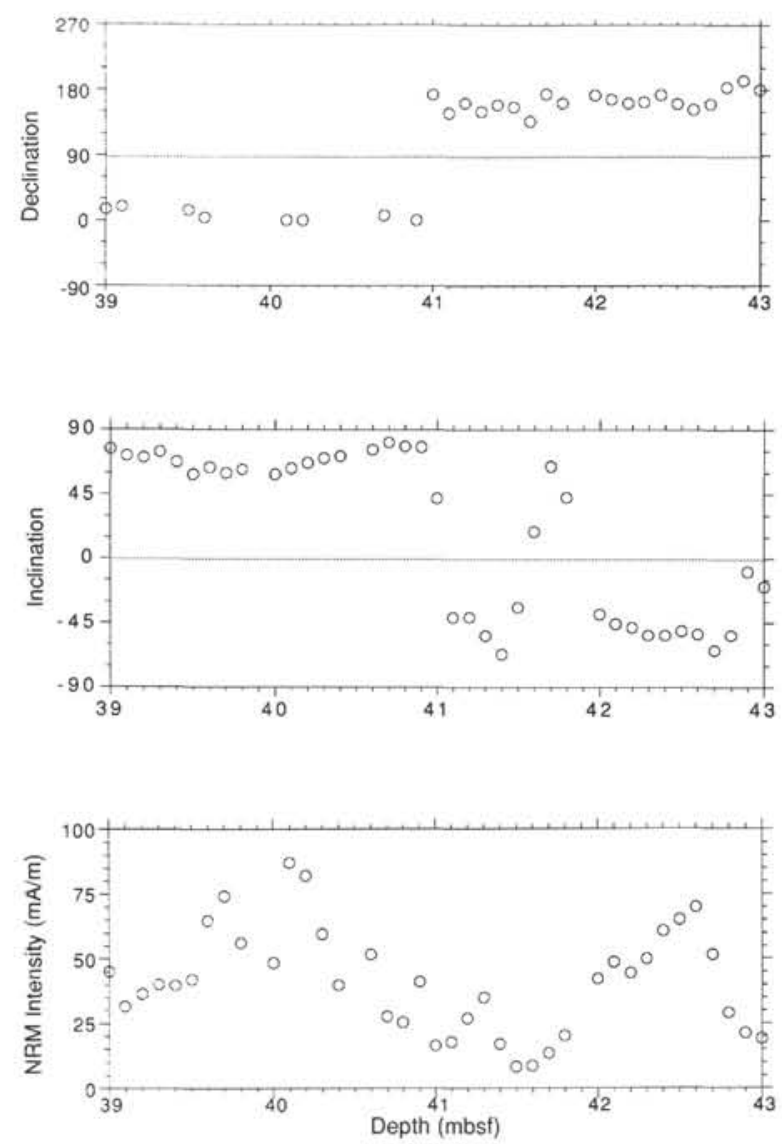

Figure 1. Declination, inclination and NRM intensity derived from shipboard measurement of the archive-halves of Cores $145-884 \mathrm{C}-5 \mathrm{H}$ and $-6 \mathrm{H}$, from 39 to $43 \mathrm{mbsf}$. Measurements were made on the pass-through cryogenic magnetometer system after AF demagnetization to $20 \mathrm{mT}$. The positive inclination zone from 41.6 to $41.8 \mathrm{mbsf}$ probably does not reflect field behavior, as the NRMs of discrete samples from this interval were reversed, whereas the archive-half declination values remain fairly constant.

$\mathrm{mT}$. In a final experiment, these same two samples were remagnetized in the $600 \mathrm{mT}$ electromagnetic field, and their resultant IRMs subjected to continuous thermal demagnetization, with the surviving magnetizations measured at progressively higher temperatures in the cryogenic magnetometer.

All of the above-described measurements and characterization experiments were performed in the paleomagnetic laboratory at the University of California, Santa Barbara (UCSB).

\section{MAGNETIC CHARACTER OF THE SAMPLES}

The acquisition and AF demagnetization of high field IRM for the two pilot samples of variable intensity and field directions are shown in Figure 2. The near saturation of both samples' IRMs by $300 \mathrm{mT}$, along with their near total loss of IRM by $580^{\circ} \mathrm{C}$ and NRM by $530^{\circ} \mathrm{C}$ precludes any significant presence of fine-grained hematite, but instead suggest magnetite or low titanium titanomagnetite as the principal remanent carrying phase. The relatively high NRM intensities (up to $8 \times 10^{-2} \mathrm{~A} / \mathrm{m}$ ) are also consistent with a magnetic mineralogy dominated by magnetite. The near symmetry of the IRM acquisition and demagnetization curves, with the normalized IRM intensity at the crossover point $(\underline{R})$ equal to $0.38(\underline{R}=0.5$ would indicate complete symmetry resulting from non-interacting single domain behavior) and the moderately high remanent coercive force $\left(\mathrm{H}_{\mathrm{rc}}\right)$ values of $\sim 45$ $\mathrm{mT}$ indicate a dominantly fine grain size (pseudo-single domain) of the remanence carriers (Cisowski, 1981).

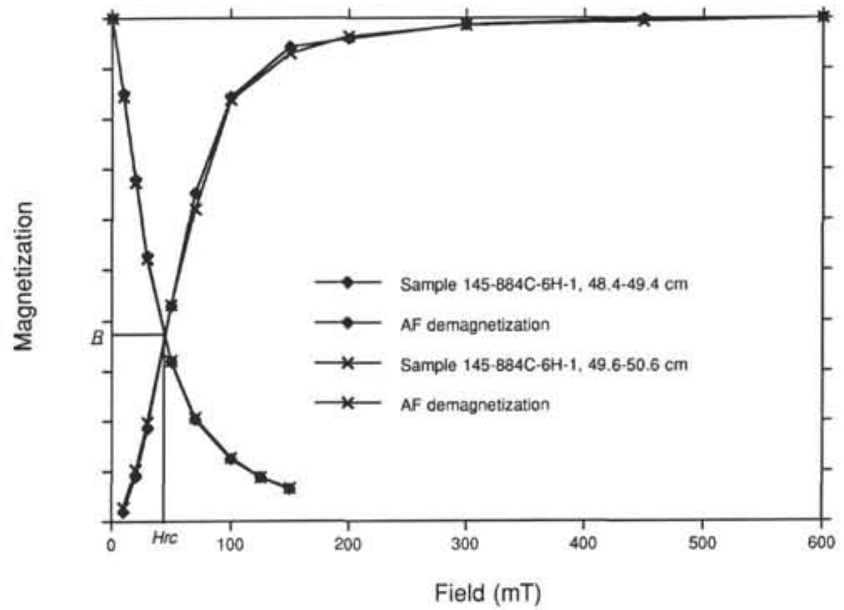

Figure 2. Acquisition and demagnetization of isothermal remanent magnetization (IRM) for adjacent low ARM-normalized intensity (0.06), low VGP latitude $\left(26.7^{\circ}\right)$ and high ARM-normalized intensity (0.10), and high VGP latitude $\left(63.5^{\circ}\right)$ samples. The intersection point of the acquisition and demagnetization curves define the $R$ value on the magnetization axis and the remanent coercive force $\left(\mathrm{H}_{\mathrm{rc}}\right)$ on the field axis (Cisowski, 1981).

\section{MAGNETIC REMANENCE RESULTS}

Figure 3 presents typical AF demagnetization behavior for two pairs of weak and strong samples from above and below the polarity transition horizon. The NRMs of nearly all of the measured samples included a vertical upward component that was easily removed by demagnetization to $5 \mathrm{mT}$. This soft overprint probably represents a remanence acquired during drilling because of drill stem magnetization. After removal of this secondary component, the magnetization generally decays toward the origin, thus defining the ChRM.

Thermal demagnetization was found to be less effective than AF demagnetization in removing the drill stem overprint, as illustrated in Figure 4. In the top pair of samples, the remanence direction of the $\mathrm{AF}$-demagnetized specimen immediately migrates to a higher normal inclination after cleaning at $5 \mathrm{mT}$, whereas the thermally demagnetized specimen persists at lower inclinations throughout the heating process. A separate thermal demagnetization experiment on a Hole $884 \mathrm{C}$ sample with a $0-30 \mathrm{mT}$ IRM induced in the $Y$ direction and a $30-600 \mathrm{mT}$ IRM induced in the $X$ direction indicated that the low coercivity IRM was not preferentially removed below $525^{\circ} \mathrm{C}$. In the bottom two samples, remanence directions are compared after the thermally demagnetized sample was initially $\mathrm{AF}$ demagnetized to $5 \mathrm{mT}$. In this case, the inclinations show a better match, although the thermally demagnetized sample retains a slightly lower normal inclination.

Figure 5 summarizes the downhole variations in the inclinations, declinations, and ARM-normalized NRM intensities (both after demagnetization to $20 \mathrm{mT}$ ) for the ChRM vectors across the polarity transition zone. Figure 6 shows the virtual geomagnetic pole (VGP) path for this same interval, as compared with another Matuyama/ Brunhes reversal path that I obtained earlier from Leg 126 Hole 792A, which was drilled about $300 \mathrm{~km}$ south of Tokyo. Both pre-transition VGP paths feature several short-lived equatorial excursions in the vicinity of the Galapagos Islands. In Figure 5, these low-latitude VGP samples, along with the first positive (normal) inclination sample from the reversal per se, are represented by filled squares. On the NRM/ARM intensity plot, these points occur at cyclical normalized intensity lows spaced about $10 \mathrm{~cm}$ apart.

\section{DISCUSSION}

The Hole 884 C Matuyama/Brunhes polarity transition record contains a number of interesting details that may shed additional light on the mechanisms of geomagnetic polarity reversals. First among these 

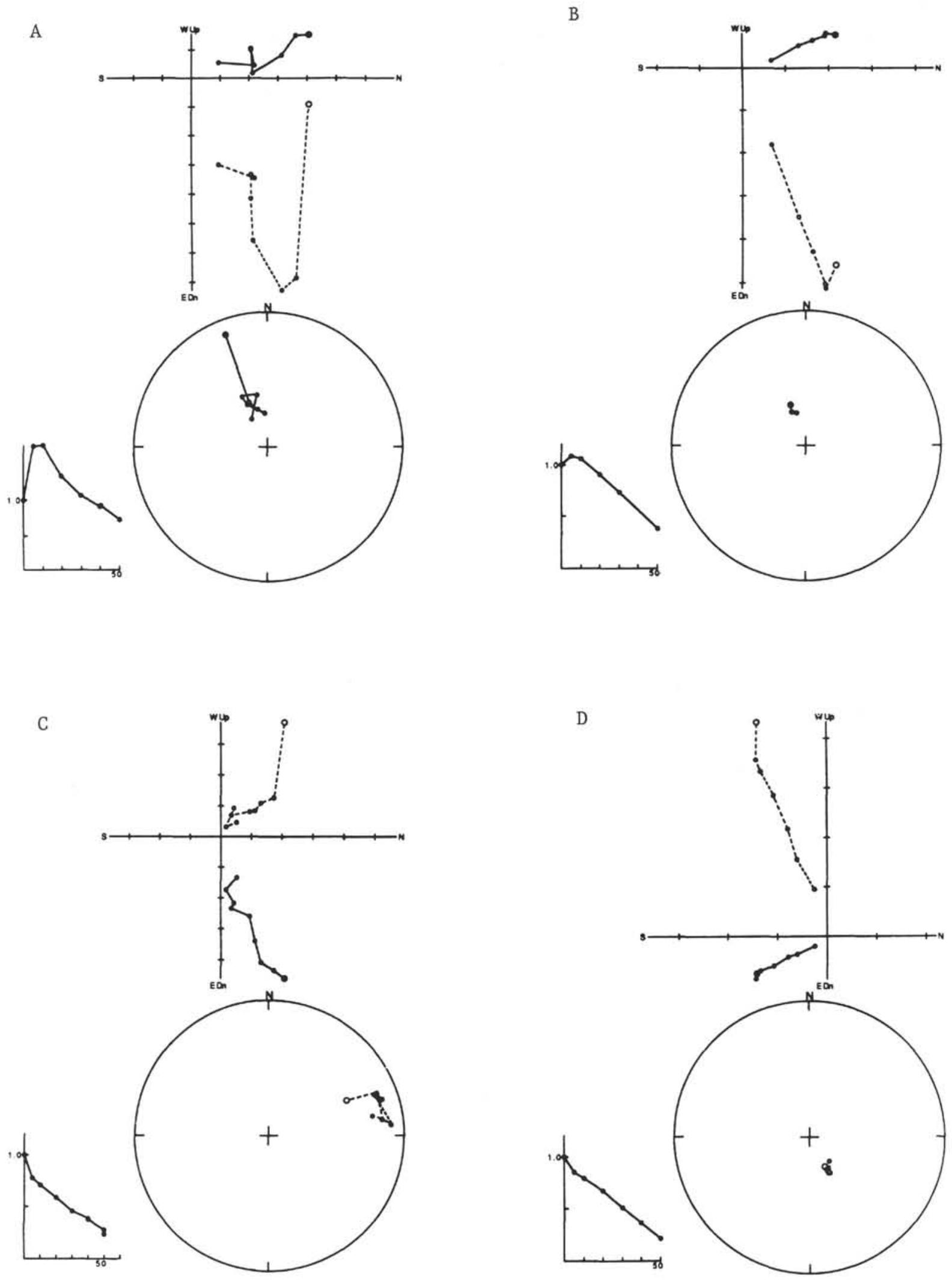

Figure 3. AF demagnetization behavior, including orthogonal components, remanence directions, and intensity plots, for (A) Sample 145-884C-6H-1, 36.7-37.7 $\mathrm{cm}$, with low (0.025) ARM-normalized intensity, and (B) Sample 145-884C-6H-1,54.0-55.0 cm, with high (0.172) ARM-normalized intensity, both samples from above the polarity transition; and for (C) Sample 145-884C-6H-1, 62.1-63.1 cm, with low (0.027) ARM-normalized intensity, and (D) Sample 145-884C-6H-1, 78.8-79.8 cm, with high (0.083) ARM-normalized intensity, both samples from below the polarity transition. Open circles on the remanence direction plot are upper hemisphere $(\mathrm{R})$, and solid circles are lower hemisphere $(\mathrm{N})$. 

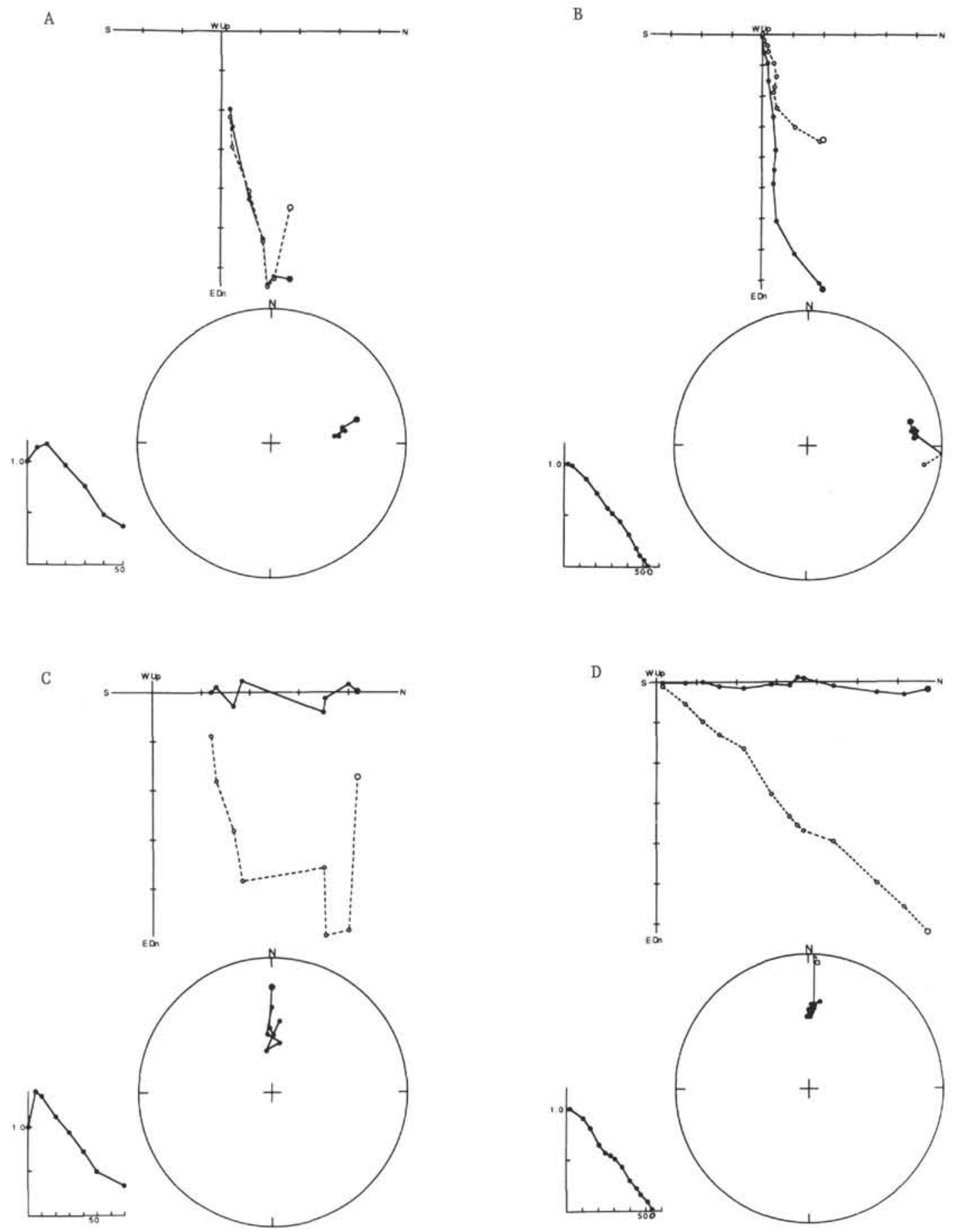

Figure 4. AF (A) vs. thermal (B) demagnetization behavior, including orthogonal components, remanence directions, and intensity plots, for two samples taken at identical depths of $48.4-49.4 \mathrm{~cm}$ in Section 145-884C-6H-1 (40.889 mbsf). AF (C) vs. thermal (D) demagnetization behavior, after AF demagnetization to $5 \mathrm{mT}$, for samples taken from identical depths of $23.8 \mathrm{~cm}$ in Section $145-884 \mathrm{C}-6 \mathrm{H}-1$ ( $40.643 \mathrm{mbsf}$ ). For the second thermally demagnetized sample, the initial migration of the field vector from a shallow reversed to a normal inclination resulted from $5 \mathrm{mT} \mathrm{AF}$ demagnetization. Open circles on the remanence direction plots are upper hemisphere $(\mathrm{R})$, and solid circles are lower hemisphere $(\mathrm{N})$.

is that the normalized sample intensities do not describe a broad featureless low centered on the pole transition, as is the case for many other reversal records. Instead, the intensities appear to oscillate widely between values equal to or even greater than those of samples from at, or just before, the onset $(41.25-41.35 \mathrm{mbsf})$ of the zone of intensity instability, and values $10 \%$ to $40 \%$ of those. Most interesting is the pronounced intensity high (40.90-40.94 mbsf), which appears immediately above the polarity transition horizon (Fig. 5). In this interval the normalized intensity is approximately double that of pre-transition values. While a similar feature has not been reported in other Matuyama/Brunhes records, a short-lived but dramatic increase in dipole field strength appears to be associated with the Lake Mungo excursion at $\sim 30$ k.y. (Barbetti and McElhinny, 1976; Shipboard Scientific Party, 1995).

On the logarithmic normalized intensity plot of Figure 7, the seven samples defining intensity troughs (solid symbols) are spaced about 
$9 \mathrm{~cm}$ apart, which represents about 1.9 k.y. based on the average sedimentation rate for this part of Hole $884 \mathrm{C}$. For trough samples that are within a $30-\mathrm{cm}$ interval centered on the polarity transition horizon at $40.96 \mathrm{mbsf}$, VGP latitudes all fall below $40^{\circ}$.

Figure 7 also shows that no apparent correlation exists between the oscillations in normalized intensity and two rock magnetic ratios that relate to magnetic grain size. These are the coercivity spectrum of $\mathrm{ARM}$ (as measured by the ratio of $\mathrm{ARM}$ remaining after $\mathrm{AF}$ demagnetization to $20 \mathrm{mT}$ to initial ARM) and the initial susceptibility over ARM, which are plotted at the top of the intensity figure. The latter ratio suggests a coarsening of the magnetic grain size toward the top of the measured section, as reflected by a decrease in the ARM over susceptibility ratio (King et al., 1983). A plot of ARM vs. susceptibility in Figure 8 reveals that the samples collected from the top of the measured transition interval at 40.618-40.776 mbsf (solid squares and dashed line) define a separate trend from those collected from 40.876 to the bottom of the study interval (solid line), with samples from between these two regions occupying a middle ground on the plot. As further evidence that the normalized intensity oscillations do not result from some periodic variation in magnetic grain size, Figure 9 shows that there is no apparent systematic difference in the ARM coercivity spectra of four weak (NRM/ARM < 0.06 ) samples vs. four strong (NRM/ARM $>0.08$ ) samples.

A second significant result of this study concerns the apparent sharpness of the field direction transition, as evidenced by the inclination vs. depth and VGP vs. depth plots of Figures 5 and 7, respectively. Again, using the average sedimentation rate of $46.9 \mathrm{~m} / \mathrm{m} . \mathrm{y}$, the time for the VGP to move from moderately high southern to high northern latitudes, which is accomplished over only $2 \mathrm{~cm}$, is only on the order of $0.4 \mathrm{k} . \mathrm{y}$. This corresponds to an average VGP velocity of $0.65^{\circ}$ of latitude per year, as calculated from the indicated VGP latitudes for the samples involved. Likewise, the three pre-transition equatorial excursions imply VGP transport rates of $0.29^{\circ}, 0.49^{\circ}$, and $0.63^{\circ}$ per year. Whether VGP movement during these short episodes is continuous or episodic (Coe and Prevot, 1989) is probably beyond the resolution of any sedimentary reversal study.

The third point of interest is the preference of the Hole 884C VGPs with latitude $<45^{\circ}$ for the Americas, not only during the principal equatorial crossing of the VGP at $\sim 40.96 \mathrm{mbsf}$, but also for the short equatorial excursions preceding the reversal, and the longer postreversal excursion into western North America (Fig. 6). Previous studies of predominantly older reversals have noted this same longitudinal preference (Laj et al., 1991), which has been related to flow patterns in the outer core, or to the shielding effect of the supposed high conductivity of the lower mantle beneath the Pacific (Runcorn, 1992). Earlier high sample-density studies of the Matuyama/Brunhes transition have displayed a variety of VGP paths, with some traversing the Americas (Clement and Kent, 1991), but others nearly antipodal (Okada and Miitsuma, 1989; Valet et al., 1989).

Figure 10 illustrates that the preference for VGP latitudes near $270^{\circ}$ extends to the high southern latitude poles from well before the polarity transition at $\sim 41$ mbsf. Future measurements on samples from greater depths in this hole may determine whether this preference reflects field behavior or incomplete removal of a present field overprint. Another interesting aspect of this plot is the total lack of poles from a $60^{\circ}$ wide band centered on the $180^{\circ}$ meridian, or the middle of the Pacific Ocean. This band also includes the sampling site longitude, which is of additional interest as VGP reversal paths are often displaced toward longitudes $90^{\circ}$ away from the site longitude (McFadden et al., 1993).

All three of these findings: that is, the pronounced oscillations in normalized intensity associated with the transition zone, the rapid movement of the VGP from the high Northern to the high Southern hemispheres during one of the deepest of the intensity troughs, and the preference of the pre-transition and transition VGPs for longitudes associated with the Americas (Fig. 6B), are consistent with my previous Matuyama/Brunhes reversal study on high accumulation
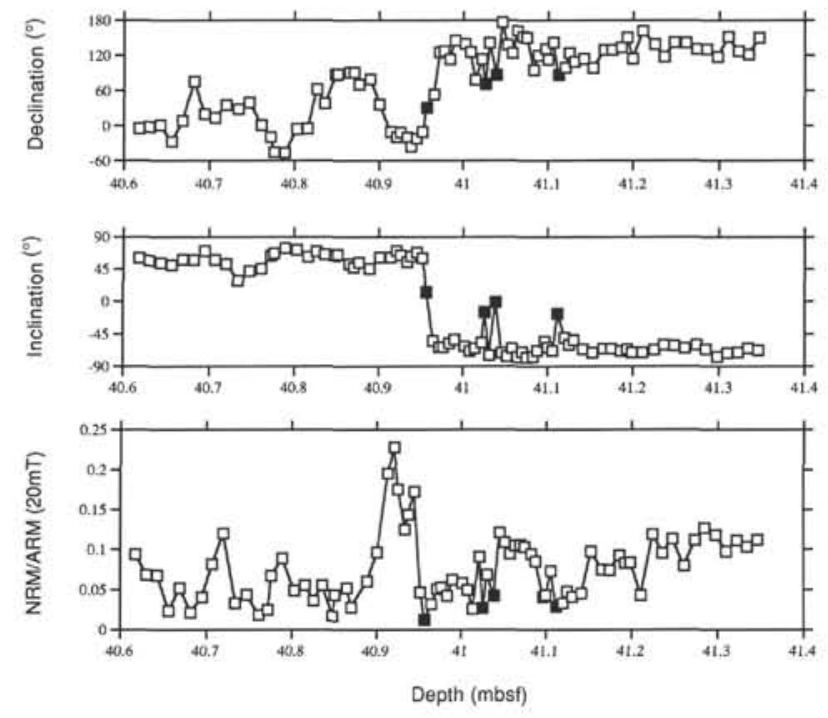

Figure 5. Declination, inclination, and ARM-normalized intensity vs, depth. Samples displaying low inclinations are emphasized as solid squares. Both $\mathrm{NRM}$ and $\mathrm{ARM}$ intensities are after AF demagnetization to $20 \mathrm{mT}$.

rate sediments from the Izu-Bonin forearc basin, about $3500 \mathrm{~km}$ southwest of Hole 884C (Cisowski and Koyama, 1992). That the variable normalized intensities noted in the previous study reflect true periodic oscillations in geomagnetic intensity is supported by recent ${ }^{10} \mathrm{Be}$ analyses on the same sediment samples (Athanassopoulos et al., 1993). As this radioactive isotope of beryllium is produced in the upper atmosphere in inverse proportion to the strength of the geomagnetic field, its abundance in sediments can give an independent assessment of geomagnetic field strength (Raisbeck et al., 1985). In the Leg 126 study, at least two sharp oscillations in the ${ }^{10} \mathrm{Be} /{ }^{9} \mathrm{Be}$ ratio have been detected in sediment samples whose deposition immediately preceded the VGP polarity transition. These oscillations occur within a broader region of high ${ }^{10} \mathrm{Be} /{ }^{9} \mathrm{Be}$ ratios (i.e., low field intensity), centered on the reversal horizon.

A simple model to describe the correlations between field intensity and direction in the Hole $884 \mathrm{C}$ reversal record would consist of a pre-transition equatorial dipole situated near the $270^{\circ}$ meridian, whose intensity would initially fluctuate in phase and proportion to the main (polar) dipole. The effect of this secondary dipole would be to bias the pre-transition VGPs toward the $270^{\circ}$ meridian (Fig. 10). About 3 k.y. before the polarity transition (41.11 mbsf in Fig. 7), the two dipole intensities decouple in intensity, such that diminution of the main dipole intensity results in migration of the VGP to the equatorial dipole direction. This continues for two cycles; however, on the third intensity cycle, the main dipole decays to zero and returns in the opposite polarity. The first intensity low after the polarity reversal is accompanied by VGP migration to western North America (Fig. 6A), implying the continued existence of the equatorial dipole. However, at about 3 k.y. after the reversal ( $40.81 \mathrm{mbsf}$ ), the equatorial dipole diminishes in prominence, as the high-latitude VGPs that dominate after this point do not show a strong longitudinal preference (Fig. 10).

\section{CONCLUSIONS}

The Hole $884 \mathrm{C}$ Matuyama/Brunhes reversal study has produced a highly detailed polarity transition record that seems to contain important information concerning the relationship between directional and intensity variations in the transition zone. Chief among these is that the geomagnetic field undergoes apparent large-magnitude oscillations in intensity, with a period of approximately 1.9 k.y., during an overall transition period of about 14 k.y. The actual polarity reversal occurs during the fourth of the seven observed cycles, when 

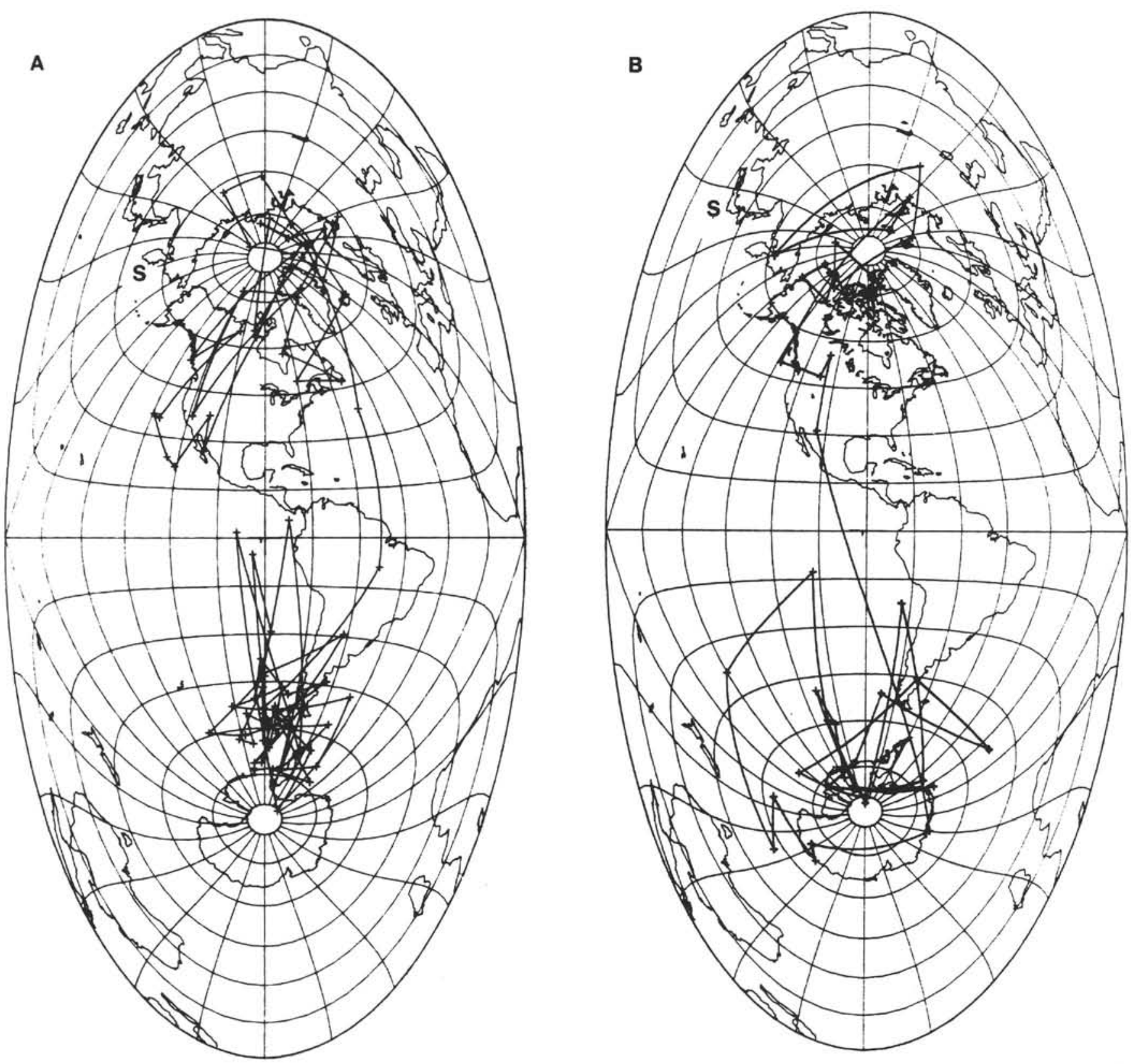

Figure 6. VGP path for the Matuyama/Brunhes transition period (A) as recorded in Hole 884C, (B) as compared with the record from Leg 126 Hole 792A (updated from Cisowski and Koyama, 1992). $\mathbf{S}$ indicates sampling sites.

the field decays to its lowest observed levels, but it returns to its highest observed levels while in the opposite polarity. These intensity oscillations, especially when they occur within about 3 k.y. of the reversal horizon, are accompanied by the rapid movement of the VGP to low latitudes, with a preference for longitudes near $270^{\circ}$. The significance of this latter observation is complicated by the fact that, as with many other reversal studies, the preferred pole path is about $90^{\circ}$ removed from the sampling site. The observed data can be modeled with the addition of an equatorial dipole to the main dipole field during the transition zone. Additional high-quality reversal studies with sampling sites nearer to the $90^{\circ}$ or $270^{\circ}$ meridians are needed to determine whether this inferred equatorial dipole has real physical significance to the reversal dynamics of the core.

\section{ACKNOWLEDGMENTS}

The author thanks J.R. Dunn for his assistance in the completion of this study, M. Fuller and R. Weeks for discussions relating to interpre- tations of these results, and J. Athanassopoulos and A. Roberts for assistance in obtaining the samples.

\section{REFERENCES}

Athanassopoulos, J., Cisowski, S.M., Lea, D.W., Fuller, M., Weeks, R., Lal, D., and Southon, J., 1993. Correlation of ${ }^{10}$ Be with magnetic intensity data for the Matuyama-Brunhes polarity reversal in high sedimentation rate marine sediments from the Izu-Bonin Arc. Eos, 74:110. (Abstract)

Barbetti, M.F., and McElhinny, M.W., 1976. The Lake Mungo geomagnetic excursion. Philos. Trans. R. Soc. London A, 281:515-542.

Cisowski, S., 1981. Interacting vs. non-interacting single domain behavior in natural and synthetic samples. Phys. Earth Planet. Inter, 26:56-62.

Cisowski, S.M., and Koyama, M., 1992. Detailed record of the Brunhes/Matuyama polarity reversal in high sedimentation rate marine sediments from

\footnotetext{
Abbreviations for names of organizations and publications in ODP reference lists follow the style given in Chemical Abstracts Service Source Index (published by American Chemical Society).
} 
the Izu-Bonin Arc. In Taylor, B., Fujioka, K., et al.,Proc. ODP, Sci. Results, 126: College Station, TX (Ocean Drilling Program), 341-352.

Clement, B.M., and Kent, D.V., 1991. A Southern Hemisphere record of the Matuyama-Brunhes polarity reversal. Geophys. Res. Lett., 18:81-84.

Coe, R.S., and Prevot, M., 1989. Evidence suggesting extremely rapid field variation during a geomagnetic reversal. Earth Planet. Sci. Lett., 92:292298.

King, J.W., Banerjee, S.K., and Marvin, J., 1983. A new rock-magnetic approach to selecting sediments for geomagnetic paleointensity studies: application to paleointensity for the last 4000 years. J. Geophys. Res., 88:5911-5921.

Kirschvink, J.L., 1980. The least-squares line and plane and analysis of palaeomagnetic data. Geophys. J. R. Astron. Soc., 62:699-718.

Laj, C., Mazaud, A., Weeks, R., Fuller, M., and Herrero-Bervera, E., 1991. Geomagnetic reversal paths. Nature, 351:447.

McFadden, P.L., Barton, C.E., and Merrill, R.T., 1993. Do virtual geomagnetic poles follow preferred paths during geomagnetic reversals? Nature, $361: 342-344$

Okada, M., and Niitsuma, N., 1989. Detailed paleomagnetic records during the Brunhes-Matuyama geomagnetic reversal, and a direct determination
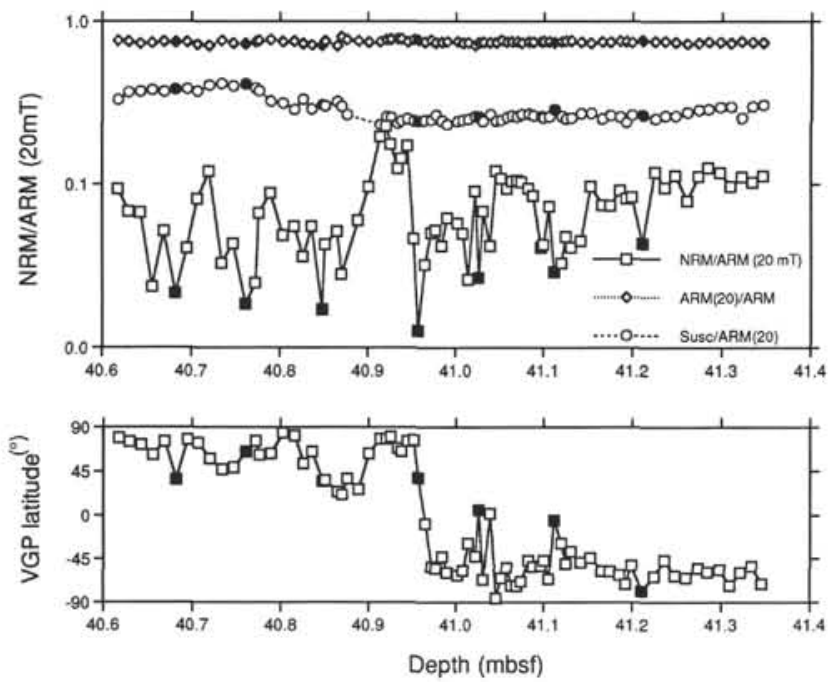

Figure 7. Logarithmic plot of ARM-normalized intensity, including two magnetic grain-size related parameters (see text) vs. depth, and linear plot of VGP latitude vs. depth. Samples defining intensity cycle lows are emphasized with solid symbols. Both NRM and ARM intensities are after AF demagnetization to $20 \mathrm{mT}$.

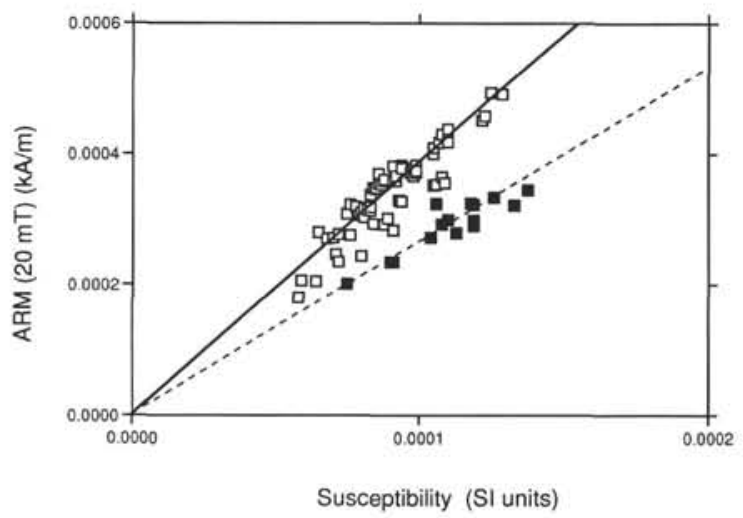

Figure 8. Demagnetized ARM vs. initial susceptibility. Solid squares are for samples collected in the interval from 40.62 to 40.78 mbsf. of depth lag for magnetization in marine sediments. Phys. Earth Planet. Inter., 56:133-150.

Raisbeck, G.M., Yiou, F., Bourles, D., and Kent, D.V., 1985. Evidence for an increase in cosmogenic ${ }^{10} \mathrm{Be}$ during a geomagnetic reversal. Nature, 315:315-317.

Runcorn, K., 1992. Polar path of geomagnetic reversals. Nature, 356:654-656. Shipboard Scientific Party, 1993. Site 884. In Rea, D.K., Basov, I.A., Janecek, T.R., Palmer-Julson, A., et al., Proc. ODP, Init. Repts., 145: College Station, TX (Ocean Drilling Program), 209-302.

, 1995. Site 930. In Flood, R.D., Piper, D.J.W., Klaus, A., et al., Proc. ODP, Init. Repts., 155: College Station, TX (Ocean Drilling Program), $87-122$.

Valet, J.-P., Tauxe, L., and Clement, B., 1989. Equatorial and mid-latitude records of the last geomagnetic reversal from the Atlantic Ocean. Earth Planet. Sci. Lett., 94:371-384.

Date of initial receipt: 31 March 1994

Date of acceptance: 18 July 1994

Ms 145SR-151

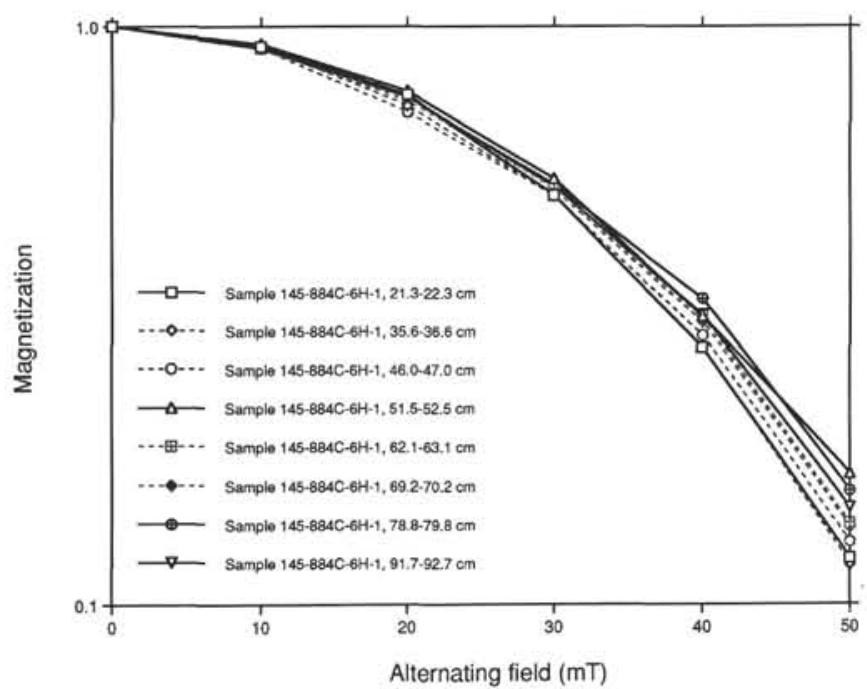

Figure 9. A comparison of AF demagnetization of ARM for samples with strong (solid lines) and weak (dashed lines) normalized intensities.

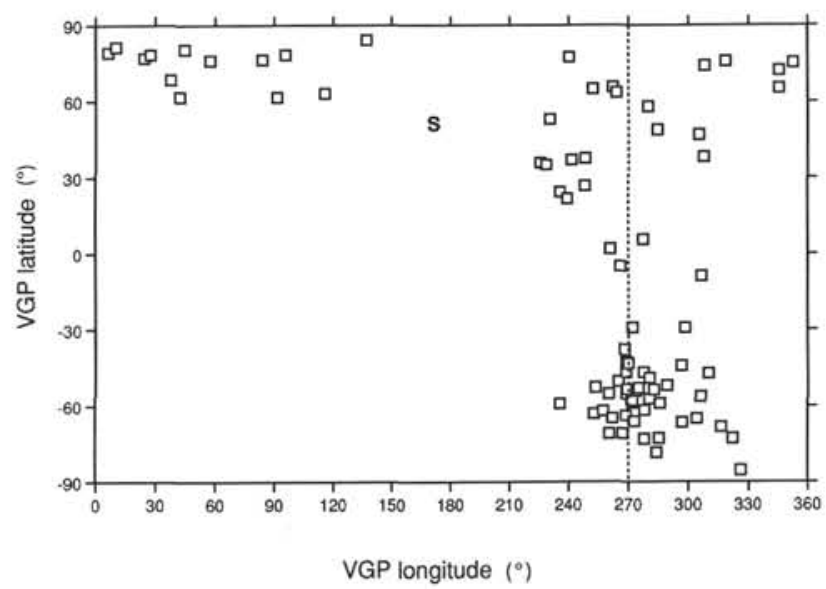

Figure 10. VGP latitude vs. VGP longitude. $\mathrm{S}$ indicates position of sampling site. Dashed line defines $270^{\circ}$ longitudinal meridian. 
APPENDIX

Hole $884 \mathrm{C}$ data

\begin{tabular}{|c|c|c|c|c|c|c|c|c|c|c|c|}
\hline $\begin{array}{l}\text { Depth } \\
\text { (mbsf) }\end{array}$ & $\begin{array}{c}\text { NRM } \\
(20 \mathrm{mT})\end{array}$ & $\begin{array}{c}\text { NRM/ARM } \\
(20 \mathrm{mT})\end{array}$ & Inclination & Declination & $\begin{array}{c}\text { VGP } \\
\text { latitude }\end{array}$ & $\begin{array}{c}\text { VGP } \\
\text { longitude }\end{array}$ & ARM & $\begin{array}{c}\text { ARM } \\
(20 \mathrm{mT})\end{array}$ & Susceptibility & $\begin{array}{l}\operatorname{ARM}(20) / \\
\operatorname{ARM}(0)\end{array}$ & $\begin{array}{c}\text { Susc. } / \\
\text { ARM (20) }\end{array}$ \\
\hline 40.618 & $3.04 \mathrm{E}-05$ & 0.0937 & 60.2 & -4.4 & 79.24 & 6.37 & 4.2700E-04 & $3.2450 \mathrm{E}-04$ & $1.0600 \mathrm{E}-04$ & 0.759 & 0.327 \\
\hline 40.63 & $2.216 \mathrm{E}-05$ & 0.0682 & 56.2 & -1.4 & 75.27 & 352.76 & $4.3200 \mathrm{E}-04$ & $3.2500 \mathrm{E}-04$ & $1.1800 \mathrm{E}-04$ & 0.752 & 0.363 \\
\hline 40.643 & $2.02 \mathrm{E}-05$ & 0.0673 & 53.1 & 1 & 72.2 & 345.62 & 4.1100 E- 04 & $3.0000 \mathrm{E}-04$ & $1.1000 \mathrm{E}-04$ & 0.73 & 0.367 \\
\hline 40.656 & $1.19 \mathrm{E}-05$ & 0.0237 & 50.4 & -26.6 & 61.7 & 42.5 & $4.5300 \mathrm{E}-04$ & $3.3400 \mathrm{E}-04$ & $1.2600 \mathrm{E}-04$ & 0.737 & 0.377 \\
\hline 40.669 & $1.68 \mathrm{E}-05$ & 0.052 & 58.1 & 8.9 & 75.88 & 318.71 & 4.3040E-04 & $3.2300 \mathrm{E}-04$ & $1.1900 \mathrm{E}-04$ & 0.75 & 0.368 \\
\hline 40.682 & $5.904 \mathrm{E}-06$ & 0.02163 & 57.4 & 75.6 & 37.14 & 241.52 & $3.6700 \mathrm{E}-04$ & $2.7300 \mathrm{E}-04$ & $1.0400 \mathrm{E}-04$ & 0.744 & 0.381 \\
\hline 40.695 & $9.62 \mathrm{E}-06$ & 0.0409 & 69.8 & 20.4 & 77.45 & 240.25 & $3.1500 \mathrm{E}-04$ & 2.3500 E- 04 & $9.0000 \mathrm{E}-05$ & 0.746 & 0.383 \\
\hline 40.707 & $2.388 \mathrm{E}-05$ & 0.0815 & 57.7 & 13.7 & 74.03 & 308.45 & $4.0600 \mathrm{E}-04$ & $2.9300 \mathrm{E}-04$ & $1.0800 \mathrm{E}-04$ & 0.722 & 0.369 \\
\hline 40.72 & $3.36 \mathrm{E}-05$ & 0.12 & 52.1 & 35.9 & 57.93 & 280 & 3.9400 E-04 & $2.8000 \mathrm{E}-04$ & $1.1300 \mathrm{E}-04$ & 0.71 & 0.4035 \\
\hline 40.734 & $1.069 \mathrm{E}-05$ & 0.0332 & 28.2 & 28.8 & 46.89 & 305.43 & $4.2300 \mathrm{E}-04$ & $3.2200 \mathrm{E}-04$ & $1.3300 \mathrm{E}-04$ & 0.761 & 0.413 \\
\hline 40.747 & $1.31 \mathrm{E}-05$ & 0.0438 & 41.7 & 40.1 & 48.91 & 284.8 & $4.0700 \mathrm{E}-04$ & $2.9900 \mathrm{E}-04$ & $1.1900 \mathrm{E}-04$ & 0.735 & 0.398 \\
\hline 40.761 & $5.43 \mathrm{E}-06$ & 0.01866 & 45.2 & 1.3 & 65.26 & 345.57 & $4.0000 \mathrm{E}-04$ & $2.9100 \mathrm{E}-04$ & $1.1900 \mathrm{E}-04$ & 0.7275 & 0.409 \\
\hline 40.772 & 5.9E-06 & 0.0251 & 63.4 & -18.5 & 76.12 & 57.72 & $3.1400 \mathrm{E}-04$ & 2.3500E-04 & 9.1000E-05 & 0.748 & 0.387 \\
\hline 40.776 & $1.34 \mathrm{E}-05$ & 0.0667 & 66.6 & -44.9 & 61.67 & 91.58 & $2.6400 \mathrm{E}-04$ & $2.0100 \mathrm{E}-04$ & $7.5000 \mathrm{E}-05$ & 0.761 & 0.373 \\
\hline 40.789 & $1.595 \mathrm{E}-05$ & 0.0886 & 74.1 & -46.3 & 63.21 & 115.78 & $2.3300 \mathrm{E}-04$ & $1.8000 \mathrm{E}-04$ & $5.8000 \mathrm{E}-05$ & 0.7725 & 0.322 \\
\hline 40.803 & IE-05 & 0.0488 & 71.5 & -5.3 & 84.31 & 137.14 & 2.7400E-04 & $2.0500 \mathrm{E}-04$ & $6.4000 \mathrm{E}-05$ & 0.748 & 0.312 \\
\hline 40.816 & $1.139 \mathrm{E}-05$ & 0.0553 & 62.1 & -4.4 & 81.38 & 10.2 & $2.7300 \mathrm{E}-04$ & $2.0600 \mathrm{E}-04$ & $5.9000 \mathrm{E}-05$ & 0.755 & 0.286 \\
\hline 40.826 & $8.83 \mathrm{E}-06$ & 0.0362 & 69.4 & 62.3 & 53.05 & 230.61 & 3.3400E-04 & $2.4400 \mathrm{E}-04$ & $8.0000 \mathrm{E}-05$ & 0.73 & 0.328 \\
\hline 40.836 & 1.371E-05 & 0.0555 & 65.3 & 38.5 & 64.93 & 252.34 & $3.4500 \mathrm{E}-04$ & $2.4700 \mathrm{E}-04$ & $7.1000 \mathrm{E}-05$ & 0.716 & 0.287 \\
\hline 40.848 & 1.379E-05 & 0.0171 & 63.2 & 86.6 & 35.2 & 228.6 & 3.3000E-04 & $2.3500 \mathrm{E}-04$ & $7.2000 \mathrm{E}-05$ & 0.712 & 0.306 \\
\hline 40.851 & $1.26 \mathrm{E}-05$ & 0.043 & 65.1 & 87.9 & 36.06 & 225.6 & $3.8740 \mathrm{E}-04$ & $2.9300 \mathrm{E}-04$ & 8.8000 E- 05 & 0.756 & 0.3 \\
\hline 40.865 & $1.47 \mathrm{E}-05$ & 0.0517 & 51.9 & 91.1 & 24.23 & 235.92 & 4.0100E-04 & $2.8400 \mathrm{E}-04$ & $9.1000 \mathrm{E}-05$ & 0.708 & 0.32 \\
\hline 40.87 & $1.26 \mathrm{E}-05$ & 0.0283 & 47.1 & 90.5 & 21.46 & 239.45 & $4.4000 \mathrm{E}-04$ & $3.5280 \mathrm{E}-04$ & $1.0500 \mathrm{E}-04$ & 0.802 & 0.298 \\
\hline 40.876 & & & 53.8 & 70.5 & 37.8 & 248.43 & $4.0650 \mathrm{E}-04$ & $3.1360 \mathrm{E}-04$ & $8.3000 \mathrm{E}-05$ & 0.771 & 0.2647 \\
\hline 40.889 & $1.5 \mathrm{E}-05$ & 0.0602 & 45 & 79.7 & 26.71 & 248.44 & $3.2900 \mathrm{E}-04$ & $2.4900 \mathrm{E}-04$ & & 0.757 & \\
\hline 40.901 & 2.39E-05 & 0.0963 & 61.1 & 36.8 & 63.49 & 264.23 & 3.3300E-04 & 2.4800 E- 04 & & 0.745 & \\
\hline 40.914 & $5.48 \mathrm{E}-05$ & 0.195 & 60.9 & -9.9 & 78.33 & 27.57 & $3.7500 \mathrm{E}-04$ & $2.8100 \mathrm{E}-04$ & $6.5000 \mathrm{E}-05$ & 0.749 & 0.231 \\
\hline 40.921 & $7.08 \mathrm{E}-05$ & 0.22765 & 69.7 & -18.8 & 78.4 & 95.91 & $4.0400 \mathrm{E}-04$ & $3,1100 \mathrm{E}-04$ & $8.0000 \mathrm{E}-05$ & 0.77 & 0.257 \\
\hline 40.926 & $5.57 \mathrm{E}-05$ & 0.1752 & 63.9 & -11.4 & 80.45 & 44.89 & $4.1000 \mathrm{E}-04$ & $3.1800 \mathrm{E}-04$ & $8.1000 \mathrm{E}-05$ & 0.776 & 0.255 \\
\hline 40.934 & $4.03 \mathrm{E}-05$ & 0.1248 & 55 & -19.8 & 68.7 & 37.69 & 4.1400E-04 & $3.2300 \mathrm{E}-04$ & $7.6000 \mathrm{E}-05$ & 0.78 & 0.235 \\
\hline 40.938 & $4.44 \mathrm{E}-05$ & 0.1437 & 62.6 & -35 & 65.56 & 262.28 & $3.9560 \mathrm{E}-04$ & $3.0900 \mathrm{E}-04$ & $7.5000 \mathrm{E}-05$ & 0.781 & 0.243 \\
\hline 40.945 & $4.67 \mathrm{E}-05$ & 0.1723 & 67.8 & -21.7 & 76.41 & 84.04 & $3.6200 \mathrm{E}-04$ & $2.7100 \mathrm{E}-04$ & $6.8000 \mathrm{E}-05$ & 0.749 & 0.251 \\
\hline 40.952 & $1.63 \mathrm{E}-05$ & 0.0468 & 59.7 & -10 & 77.1 & 24.58 & $4.5100 \mathrm{E}-04$ & $3.4800 \mathrm{E}-04$ & $8.5000 \mathrm{E}-05$ & 0.772 & 0.244 \\
\hline 40.957 & 4.4E-06 & 0.01268 & 12.7 & 30.9 & 38.24 & 307.82 & 4.5100E-04 & $3.4700 \mathrm{E}-04$ & $8.4000 \mathrm{E}-05$ & 0.769 & 0.242 \\
\hline 40.965 & $1.16 \mathrm{E}-05$ & 0.0323 & -55 & 53.6 & -8.83 & 306.82 & 4.8000 E- 04 & $3.5860 \mathrm{E}-04$ & $8.8000 \mathrm{E}-05$ & 0.747 & 0.245 \\
\hline 40.972 & $1.71 \mathrm{E}-05$ & 0.0506 & -63 & 125 & -53.41 & 269.6 & $4.4100 \mathrm{E}-04$ & $3,3800 \mathrm{E}-04$ & $8.3000 \mathrm{E}-05$ & 0.766 & 0.246 \\
\hline 40.977 & $1.972 \mathrm{E}-05$ & 0.0526 & -63.5 & 127.4 & -55.19 & 269.03 & $5.0700 \mathrm{E}-04$ & $3.7500 \mathrm{E}-04$ & $9.9000 \mathrm{E}-05$ & 0.74 & 0.264 \\
\hline 40.984 & $1.518 \mathrm{E}-05$ & 0.042 & -58.2 & 113.6 & -43.25 & 270.02 & $4.8500 \mathrm{E}-04$ & $3.6100 \mathrm{E}-04$ & $8.8000 \mathrm{E}-05$ & 0.744 & 0.244 \\
\hline $\begin{array}{l}40.99 \\
40.996\end{array}$ & $2.304 \mathrm{E}-05$ & 0.06227 & -52.8 & 145.5 & -59.22 & 235.89 & $4.9300 \mathrm{E}-04$ & $3.7000 \mathrm{E}-04$ & $8.6000 \mathrm{E}-05$ & 0.75 & 0.232 \\
\hline 41.002 & $2.06 \mathrm{E}-05$ & 0.058 & -62.1 & 139.7 & -61.95 & 257.64 & $4.7300 \mathrm{E}-04$ & $3.5500 \mathrm{E}-04$ & $8.6000 \mathrm{E}-05$ & 0.75 & 0.242 \\
\hline 41.008 & $1.91 \mathrm{E}-05$ & 0.05 & -68.6 & 125.9 & -57.24 & 280.9 & $5.1800 \mathrm{E}-04$ & $3.8200 \mathrm{E}-04$ & $9.4000 \mathrm{E}-05$ & 0.737 & 0.246 \\
\hline 41.014 & $9.898 \mathrm{E}-06$ & 0.0262 & -65.1 & 78.5 & -29.25 & 298.51 & $5.1000 \mathrm{E}-04$ & $3.7800 \mathrm{E}-04$ & $9.4000 \mathrm{E}-05$ & 0.741 & 0.249 \\
\hline 41.022 & 1.61E-05 & 0.0904 & -57.3 & 113.5 & -42.58 & 269.05 & $3.8900 \mathrm{E}-04$ & $2.7800 \mathrm{E}-04$ & $7.2000 \mathrm{E}-05$ & 0.714 & 0.259 \\
\hline 41.026 & $7.344 \mathrm{E}-06$ & 0.027 & -14.7 & 71.4 & 5.47 & 277.6 & $3.6700 \mathrm{E}-04$ & $2.7200 \mathrm{E}-04$ & $7.0000 \mathrm{E}-05$ & 0.741 & 0.257 \\
\hline 41.031 & $2.43 \mathrm{E}-05$ & 0.06845 & -74.4 & 140.8 & -66.68 & 297.24 & $4.7700 \mathrm{E}-04$ & $3.5500 \mathrm{E}-04$ & $8.6000 \mathrm{E}-05$ & 0.744 & 0.242 \\
\hline 41.039 & $1.286 \mathrm{E}-05$ & 0.0423 & -0.7 & 86.7 & 1.78 & 261.14 & $4.1000 \mathrm{E}-04$ & $3.0400 \mathrm{E}-04$ & $8.1000 \mathrm{E}-05$ & 0.741 & 0.266 \\
\hline 41.046 & $3.87 \mathrm{E}-05$ & 0.1209 & -71.1 & 177 & -85.49 & 326.27 & $4.3100 \mathrm{E}-04$ & $3.2000 \mathrm{E}-04$ & $7.8000 \mathrm{E}-05$ & 0.742 & 0.244 \\
\hline 41.052 & 3.85E-05 & 0.10876 & -76.3 & 138.1 & -64.99 & 304.53 & 4.6200 E- 04 & $3.5400 \mathrm{E}-04$ & $8.7000 \mathrm{E}-05$ & 0.766 & 0.246 \\
\hline 41.058 & 3.37E-05 & 0.0939 & -65.1 & 123.9 & -54.06 & 274.15 & 4.8000E-04 & $3.5900 \mathrm{E}-04$ & $9.2000 \mathrm{E}-05$ & 0.748 & 0.256 \\
\hline 41.064 & $3.88 \mathrm{E}-05$ & 0.1043 & -77.3 & 161.9 & -73.02 & 322.42 & $4.9700 \mathrm{E}-04$ & $3.7200 \mathrm{E}-04$ & $9.7000 \mathrm{E}-05$ & 0.748 & 0.26 \\
\hline 41.07 & $3.24 \mathrm{E}-05$ & 0.1055 & -70.1 & 152.5 & -73.26 & 278.23 & $4.0900 \mathrm{E}-04$ & $3.0700 \mathrm{E}-04$ & $7.9000 \mathrm{E}-05$ & 0.751 & 0.257 \\
\hline 41.075 & $3.836 \mathrm{E}-05$ & 0.1031 & -78.1 & 150.1 & -68.51 & 316.43 & $5.0400 \mathrm{E}-04$ & $3.7200 \mathrm{E}-04$ & 9.9000 E- 05 & 0.738 & 0.266 \\
\hline 41.083 & $3.44 \mathrm{E}-05$ & 0.094 & -76.9 & 94.9 & -47.01 & 310.27 & $4.8900 \mathrm{E}-04$ & $3.6600 \mathrm{E}-04$ & $9.8000 \mathrm{E}-05$ & 0.748 & 0.268 \\
\hline 41.088 & $3.4 \mathrm{E}-05$ & 0.085 & -68.3 & 119.7 & -53.53 & 282.82 & $5.3560 \mathrm{E}-04$ & $4.0000 \mathrm{E}-04$ & $1.0500 \mathrm{E}-04$ & 0.747 & 0.262 \\
\hline 41.097 & 1.587E-05 & 0.0414 & -55.6 & 131.4 & -52.56 & 253.61 & $5.1100 \mathrm{E}-04$ & $3.8300 \mathrm{E}-04$ & $9.9000 \mathrm{E}-05$ & 0.7495 & 0.2585 \\
\hline 41.1 & $1.852 \mathrm{E}-05$ & 0.043 & -63.7 & 113.1 & -46.73 & 277.72 & 5.7200E-04 & $4.3100 \mathrm{E}-04$ & 1.1000E-04 & 0.753 & 0.255 \\
\hline 41.106 & $3.04 \mathrm{E}-05$ & 0.0729 & -68.2 & 141.5 & -66.26 & 273.36 & $5.5600 \mathrm{E}-04$ & $4.1700 \mathrm{E}-04$ & L.0700E-04 & 0.75 & 0.257 \\
\hline 41.112 & $8.6 \mathrm{E}-06$ & 0.02925 & -17.3 & 87 & -5.06 & 266.21 & $3.9600 \mathrm{E}-04$ & $2.9400 \mathrm{E}-04$ & $8.4000 \mathrm{E}-05$ & 0.742 & 0.286 \\
\hline 41.12 & $1.252 \mathrm{E}-05$ & 0.0331 & -50.1 & 99.4 & -29.26 & 272.28 & 5.0400 E- 04 & $3.7800 \mathrm{E}-04$ & $9.8000 \mathrm{E}-05$ & 0.75 & 0.259 \\
\hline 41.125 & $2.056 \mathrm{E}-05$ & 0.0478 & -59.7 & 123.6 & -50.4 & 265.22 & $5.6700 \mathrm{E}-04$ & $4.3000 \mathrm{E}-04$ & $1.0800 \mathrm{E}-04$ & 0.758 & 0.251 \\
\hline 41.131 & $2.042 \mathrm{E}-05$ & 0.0414 & -53.9 & 109.5 & -37.87 & 268.34 & $6.5000 \mathrm{E}-04$ & $4.9320 \mathrm{E}-04$ & $1.2500 \mathrm{E}-04$ & 0.759 & 0.253 \\
\hline 41.142 & $2.066 \mathrm{E}-05$ & 0.0451 & -66 & 114.3 & -48.99 & 280.87 & $6.1500 \mathrm{E}-04$ & 4.5800E-04 & $1.2300 \mathrm{E}-04$ & 0.745 & 0.269 \\
\hline 41.153 & 4.38E-05 & 0.0971 & -70.9 & 98.4 & -44.01 & 296.79 & $6.1200 \mathrm{E}-04$ & 4.5100E-04 & $1.2200 \mathrm{E}-04$ & 0.737 & 0.2705 \\
\hline 41.166 & 3.28E-05 & 0.0749 & -65.3 & 129.2 & -57.38 & 271.64 & 5.8300 E- 04 & 4.3800 E- 04 & $1.1000 \mathrm{E}-04$ & 0.751 & 0.251 \\
\hline 41.175 & 3.1E-05 & 0.0742 & -65.7 & 129.7 & -57.91 & 272.25 & $5.6000 \mathrm{E}-04$ & $4.1800 \mathrm{E}-04$ & $1.1000 \mathrm{E}-04$ & 0.746 & 0.263 \\
\hline 41.186 & $3.77 \mathrm{E}-05$ & 0.0922 & -68.8 & 133.3 & -61.63 & 278.49 & 5.3900 E- 04 & $4.0900 \mathrm{E}-04$ & $1.0500 \mathrm{E}-04$ & 0.759 & 0.257 \\
\hline 41.193 & $3.14 \mathrm{E}-05$ & 0.0824 & -66.1 & 150.8 & -71.1 & 260.74 & $5.0600 \mathrm{E}-04$ & $3.8100 \mathrm{E}-04$ & $9.1000 \mathrm{E}-05$ & 0.753 & 0.239 \\
\hline 41.199 & 3.13E-05 & 0.0836 & -70.4 & 114.4 & -51.85 & 289.56 & $5.0200 \mathrm{E}-04$ & $3.7400 \mathrm{E}-04$ & $9.9000 \mathrm{E}-05$ & 0.745 & 0.265 \\
\hline 41.211 & 2.13E-05 & 0.0434 & -70.8 & 161.8 & -78.55 & 284.27 & $6.4300 \mathrm{E}-04$ & $4.9100 \mathrm{E}-04$ & $1.2900 \mathrm{E}-04$ & 0.763 & 0.263 \\
\hline 41.225 & $4.37 \mathrm{E}-05$ & 0.119 & -66.4 & 139 & -63.95 & 268.96 & $4.8600 \mathrm{E}-04$ & $3.6600 \mathrm{E}-04$ & $9.2000 \mathrm{E}-05$ & 0.753 & 0.251 \\
\hline 41.236 & $3 \mathrm{E}-05$ & 0.0952 & -59.7 & 117.8 & -46.83 & 269.12 & $4.1700 \mathrm{E}-04$ & $3.1500 \mathrm{E}-04$ & $8.2000 \mathrm{E}-05$ & 0.755 & 0.26 \\
\hline 41.248 & 3.6E-05 & 0.11285 & -61.1 & 142.5 & -63.06 & 253 & $4.2800 \mathrm{E}-04$ & $3.1900 \mathrm{E}-04$ & $8.3000 \mathrm{E}-05$ & 0.745 & 0.26 \\
\hline 41.261 & $3.326 \mathrm{E}-05$ & 0.0793 & -64.6 & 141.9 & -64.9 & 262.3 & $3.7900 \mathrm{E}-04$ & $2.7670 \mathrm{E}-04$ & 7.6000 E- -05 & 0.73 & 0.275 \\
\hline 41.274 & $3.67 \mathrm{E}-05$ & 0.1115 & -59.9 & 131 & -55.12 & 260.2 & $4.4700 \mathrm{E}-04$ & $3.2900 \mathrm{E}-04$ & $9.3000 \mathrm{E}-05$ & 0.736 & 0.283 \\
\hline 41.285 & 4.15E-05 & 0.1265 & -66 & 131 & -58.87 & 272.24 & $4.3800 \mathrm{E}-04$ & $3.2800 \mathrm{E}-04$ & $9.4000 \mathrm{E}-05$ & 0.749 & 0.287 \\
\hline 41.298 & 3.56E-05 & 0.1179 & -77 & 117.8 & -56.29 & 306.41 & $4.0500 \mathrm{E}-04$ & $3.0200 \mathrm{E}-04$ & $8.9000 \mathrm{E}-05$ & 0.746 & 0.295 \\
\hline 41.31 & $3.54 \mathrm{E}-05$ & 0.097 & -71.5 & 152 & -72.94 & 285.5 & $4.9600 \mathrm{E}-04$ & $3.6500 \mathrm{E}-04$ & 1.0800E-04 & 0.736 & 0.296 \\
\hline 41.322 & $3.99 \mathrm{E}-05$ & 0.111 & -70.8 & 127.3 & -59.05 & 286.22 & $4.7800 \mathrm{E}-04$ & 3.6000E-04 & $9.1000 \mathrm{E}-05$ & 0.753 & 0.253 \\
\hline 41.334 & 3.65E-05 & 0.1031 & -65.1 & 122 & -52.92 & 275.19 & $4.7500 \mathrm{E}-04$ & $3.5400 \mathrm{E}-04$ & $1.0600 \mathrm{E}-04$ & 0.745 & 0.299 \\
\hline 41.346 & $4 \mathrm{E}-05$ & 0.112 & -67.6 & 149.8 & -71.1 & 267.39 & $4.7900 \mathrm{E}-04$ & $3.5600 \mathrm{E}-04$ & $1.0900 \mathrm{E}-04$ & 0.743 & 0.306 \\
\hline
\end{tabular}

